\title{
An Esterase Zymogram of Escherichia coli
}

\author{
By PH. GOULLET \\ Laboratoire de Microbiologie, Faculté de Médécine Xavier-Bichat, \\ Université Paris VII \\ U.E.R. Biomédicale des Cordeliers, $2 \mathrm{I}$, rue de l'Ecole de Médécine, \\ 75270 Paris Cedex 06, France
}

(Received I4 November 1972; revised 2 I February 1973)

\begin{abstract}
SUMMARY
The intracellular esterases of 25 strains of Escherichia coli, growing exponentially on a minimal medium, were analysed by the acrylamide-agarose zymogram technique.

Five kinds of esterase bands were defined: three major bands (A, B and C) and two minor ones. The A and B esterase bands hydrolysed $\alpha$-naphthyl, $\beta$-naphthyl and indoxyl acetates; they were inhibited by di-iso-fluoropropyl phosphate (DFP). Esterase band $\mathrm{B}$ also hydrolysed the $\alpha$ - and $\beta$-naphthyl butyrates and was stable at $60^{\circ} \mathrm{C}$. Esterase band $\mathrm{C}$ hydrolysed only $\beta$-naphthyl acetate and it resisted DFP. The $\mathrm{A}, \mathrm{B}$ and $\mathrm{C}$ esterase bands showed variations in electrophoretic mobility which seemed to indicate an intraspecific differentiation of molecular structures of the esterase that could have arisen during microbial evolution.
\end{abstract}

\section{INTRODUCTION}

The zymogram (Hunter \& Markert, 1957) in starch or acrylamide gels separates enzymes according to their electrical charges and molecular dimensions and indicates their activity by specific staining. Since the work of Norris (1962) its application in bacterial taxonomy has come into general use. Among the enzymes systems most frequently studied are the esterases (Norris, 1964; Lund, I965; Cann \& Willox, I965; Robinson, I966; Green \& Goldberg, I967; Nakayama \& Takeya, 1967; Colwell, Adeyemo \& Kirtland, I968; Morichi, Sharpe \& Reiter, I968; Hogan \& Colwell, I969; Murphy \& Masterson, I970; Goullet, I970; El-Sharkawy \& Huisingh, I97I $a, b$; Stewart \& Stewart, 197I). The present work, which forms part of a programme of research on the Enterobacteriaceae (Goullet, 197I), deals with the intracellular esterases (carboxylic ester hydrolases, EC. 3. I . I) of strains of Escherichia coli.

\section{METHODS}

Bacteria and growth conditions. The 25 strains of Escherichia coli listed in Table I were shaken vigorously at $37^{\circ} \mathrm{C}$ in minimal salt medium M63 (Pardee, Jacob \& Monod, I959) supplemented with $2 \mathrm{~g}$ glycerol/1. For growth of $E$. coli $\mathrm{K}-\mathrm{I} 2$ strain $2000, \mathrm{I} \mathrm{mg}$ thiamine/1 was added. L broth (Lennox, I955) without glucose was used as a rich medium. Extinction was measured at $600 \mathrm{~nm}$. The bacteria were harvested during the logarithmic phase and for some experiments during the early stationary phase.

Preparation of extracts. After centrifugation, the bacteria were washed in distilled water, suspended in $0.06 \mathrm{M}$-tris-glycine buffer, $\mathrm{pH} 8.7$, and disrupted by sonic vibration (Sonifier $\mathrm{S}$ I 25, Branson Sonic Power, Danbury, U.S.A.). Debris was removed at $20000 \mathrm{~g}$ for $20 \mathrm{~min}$ 
Table I. Strains used

\begin{tabular}{|c|c|c|c|c|}
\hline Source & \multicolumn{2}{|c|}{ Strains } & $\begin{array}{l}\text { Date of } \\
\text { isolation }\end{array}$ & $\begin{array}{l}\text { Growth } \\
\text { conditions }\end{array}$ \\
\hline \multirow{3}{*}{$\begin{array}{l}\text { Collection of F. Jacob and } \\
\text { J. Monod, Institut Pasteur, Paris }\end{array}$} & \multicolumn{2}{|c|}{$\mathrm{K}-\mathrm{I} 2$ strain 2000} & - & $a, b, c$ \\
\hline & \multicolumn{2}{|c|}{ Enteropathogenic strains } & & \\
\hline & Strain & Serotype & & \\
\hline \multirow{8}{*}{$\begin{array}{l}\text { Obtained from L. Le Minor, } \\
\text { Institut Pasteur, Paris }\end{array}$} & LM-26 & 026: B6 & 1970 & $\mathrm{a}, \mathrm{c}$ \\
\hline & LM- 55 & $055:$ B5 & 1970 & a \\
\hline & LM-86 & o86: B7 & 1970 & $\mathrm{a}$ \\
\hline & LM-I I I & OIII: B4 & 1970 & a \\
\hline & LM-I 19 & OI19: B14 & 1970 & a \\
\hline & LM-I 25 & $0125: \mathrm{B} 15$ & 1970 & $a$ \\
\hline & LM-I 26 & OI26: B16 & 1970 & $a, b$ \\
\hline & LM-I 27 & O127: B8 & 1970 & a \\
\hline \multicolumn{5}{|c|}{ Other strains } \\
\hline \multirow{3}{*}{$\begin{array}{l}\text { Laboratory of Microbiology, Faculty } \\
\text { of Medicine, Paris }\end{array}$} & \multicolumn{2}{|c|}{ FM-I } & 1968 & a \\
\hline & \multicolumn{2}{|c|}{$F M-2$} & 1968 & $\mathrm{a}, \mathrm{b}, \mathrm{c}$ \\
\hline & \multicolumn{2}{|c|}{ FM-3 } & I 968 & $\mathrm{a}$ \\
\hline \multirow{13}{*}{$\begin{array}{l}\text { Laboratory of Bacteriology, } \\
\text { Beaujon Hospital, Paris-Clichy }\end{array}$} & \multicolumn{2}{|c|}{$\mathrm{HB}-4$} & 1969 & $\mathrm{a}$ \\
\hline & \multicolumn{2}{|c|}{$\mathrm{HB}-5$} & 1969 & $\mathrm{a}$ \\
\hline & \multicolumn{2}{|c|}{ нв- 6} & 1969 & $a, c$ \\
\hline & \multicolumn{2}{|c|}{ HB- 8} & 1969 & $\mathrm{a}$ \\
\hline & \multicolumn{2}{|c|}{ HB-IO } & 1969 & $\mathrm{a}$ \\
\hline & \multicolumn{2}{|c|}{ HB-I I } & 1969 & $\mathrm{a}$ \\
\hline & \multicolumn{2}{|c|}{ HB- 12} & 1969 & $\mathrm{a}, \mathrm{c}$ \\
\hline & \multicolumn{2}{|c|}{ HB-I 3} & 1969 & $\mathrm{a}$ \\
\hline & \multicolumn{2}{|c|}{ HB-I 4} & 1969 & $\mathrm{a}$ \\
\hline & \multicolumn{2}{|c|}{ HB-I 5} & 1970 & $\mathrm{a}, \mathrm{c}$ \\
\hline & \multicolumn{2}{|c|}{ HB- 16} & 1970 & $\mathrm{a}$ \\
\hline & \multicolumn{2}{|c|}{$\mathrm{HB}-\mathrm{I} 7$} & 1970 & a \\
\hline & \multicolumn{2}{|c|}{ HB-I 8} & 1970 & $a, b, c$ \\
\hline
\end{tabular}

at $4{ }^{\circ} \mathrm{C}$. The crude extracts containing 40 to $60 \mathrm{mg}$ protein $/ \mathrm{ml}$ were frozen to $-20^{\circ} \mathrm{C}$ until analysed. Each strain was cultured and extracted at least twice.

For heat denaturation and DFP inhibition, crude extracts and esterase preparations $(5 \mathrm{mg}$ protein $/ \mathrm{ml}$ ) obtained after salting-out with ammonium sulphate ( 25 to $50 \%$ saturation) were used.

Electrophoresis. Horizontal slab electrophoresis in polyacrylamide-agarose gel was carried out as described by Uriel (I966) using 7,5 and $3 \%(\mathrm{w} / \mathrm{v}$ ) acrylamide and the discontinuous tris-glycine buffer, $\mathrm{pH} 8.7$; in some experiments the $0.01 \mathrm{M}$-phosphate buffer, $\mathrm{pH} 7$, was used. To compare relative mobilities the bacterial extracts were inserted side by side into the same gel and in some experiments the order of the extracts was changed. Bromophenol blue was the marker dye. The extracts were subjected to a constant voltage gradient of $7 \mathrm{~V} / \mathrm{cm}$ until the marker dye had travelled $13 \mathrm{~cm}$.

Staining. The esterases were stained within the gel (Lawrence, Melnick \& Weimer, 1960; Uriel, I96I) using the following specific substrates: $\alpha$-naphthyl acetate, $\beta$-naphthyl acetate, indoxyl acetate, $\alpha$-naphthyl butyrate and $\beta$-naphthyl butyrate (Sigma Chemical Co., St Louis, Missouri, U.S.A.). For examining the effect of trypsin, DFP, PHMB and heat denatu- 
Table 2. Specific activity of esterases

\begin{tabular}{|c|c|c|c|c|c|}
\hline \multirow{3}{*}{$\begin{array}{l}\text { Class of } \\
\text { esterase } \\
\text { specificity }\end{array}$} & \multicolumn{5}{|c|}{ Substrates hydrolysed } \\
\hline & \multicolumn{3}{|c|}{ Acetates } & \multicolumn{2}{|c|}{ Butyrates } \\
\hline & $\beta$-Naphthyl & $\alpha$-Naphthyl & Indoxyl & $\alpha$-Naphthyl & $\beta$-Naphthy \\
\hline I & + & - & - & - & - \\
\hline 2 & + & + & - & - & - \\
\hline 3 & + & + & + & $( \pm)$ & - \\
\hline 4 & + & + & + & + & + \\
\hline
\end{tabular}

ration, $\beta$-naphthyl acetate and indoxyl acetate were used as substrates. All the experiments were repeated and included control proteinograms. For protein staining, Amidoblack Io b (Bender \& Hobein, München, Germany) was used (Uriel, I966).

Effect of trypsin. Crude extracts were supplemented with trypsin (Calbiochem, Los Angeles, California, U.S.A.) at 2 to $10 \mathrm{mg} / \mathrm{ml}$ and incubated at $37^{\circ} \mathrm{C}$ for 2,6 and $12 \mathrm{~h}$.

Heat denaturation. The samples were heated to 60 and $70^{\circ} \mathrm{C}$ for 10 and $30 \mathrm{~min}$.

Inhibition by di-iso-fluoropropyl-phosphate (DFP). DFP (Schuchardt, München, Germany) from $10^{-4} M$ to $10^{-2} \mathrm{M}$ was added to the samples and the mixtures stood $30 \mathrm{~min}$ at room temperature immediately before electrophoresis.

Effect of p-hydroxymercuribenzoate (PHMB). PHMB (Sigma) from $10^{-4} \mathrm{M}^{-10} 10^{-2} \mathrm{M}$ was added to the crude extracts and the mixtures stood $30 \mathrm{~min}$ at room temperature.

Protein estimation. Protein was determined by the method of Lowry, Rosebrough, Farr \& Randall (195I), using bovine serum albumin as standard.

\section{RESULTS}

\section{Characteristics of esterase bands}

Specificity. All the esterases hydrolysed $\beta$-naphthyl acetate but differed in their range of activity towards other substrates. The esterase bands are classified in Table 2 according to the number and nature of the substrates hydrolysed.

Electrophoretic mobility. Fig. I shows an example of the zymograms for the Escherichia coli strains $\mathrm{K}-\mathrm{I} 2$ and $\mathrm{HB}-\mathrm{IO}$ in polyacrylamide-agarose gel using $7 \%(\mathrm{w} / \mathrm{v})$ acrylamide and discontinuous tris-glycine buffer, $\mathrm{pH} 8 \cdot 7$. The coloured bands were distributed from $E_{\mathrm{F}} \simeq 25$ to $E_{\mathrm{F}} \simeq 97$. Two minor bands occupied the extreme positions of the zymogram: the faster (F), $E_{\mathrm{F}} \simeq 97$, was thin, and reacted only with $\beta$-naphthyl acetate (specificity $\mathrm{I}$ ), the slower (S) $E_{\mathrm{F}} \simeq 25$, was diffuse and reacted with $\beta$-naphthyl acetate and to a small degree with $\beta$-naphthyl butyrate. The major bands $\mathrm{A}, \mathrm{B}$ and $\mathrm{C}$ were located between $E_{\mathrm{F}} \simeq 40$ and $E_{\mathrm{F}} \simeq$ 80 . Bands A and B hydrolysed $\alpha$-naphthyl, $\beta$-naphthyl and indoxyl acetates. Control electrophoresis demonstrated that these two bands were not the results of a migration artefact (Cann \& Goad, 1968). Bands A reacted very weakly with $\alpha$-naphthyl butyrate and they did not react with the $\beta$-naphthyl butyrate (specificity 3 ), whereas bands $\mathrm{B}$ hydrolysed both substrates (specificity 4). Bands A migrated faster than bands B; these showed two types of mobility: $\mathrm{B}_{1}\left(E_{\mathrm{F}} \simeq 70\right)$ from $E$. coli $\mathrm{K}-12 ; \mathrm{B}_{2}\left(E_{\mathrm{F}} \simeq 60\right)$ from $E$. coli $\mathrm{HB}-\mathrm{IO}$. Bands $\mathrm{C}$ reacted only with $\beta$-naphthyl acetate (specificity $\mathrm{I}$ ); other characteristics will be considered later. Finally, a band I (intermediate) active towards $\alpha$ - and $\beta$-naphthyl acetate (specificity 2 ) was often observed; its position on the zymogram varied with the strain under examination.

Results obtained with other buffers and with agarose gel confirmed the observations 

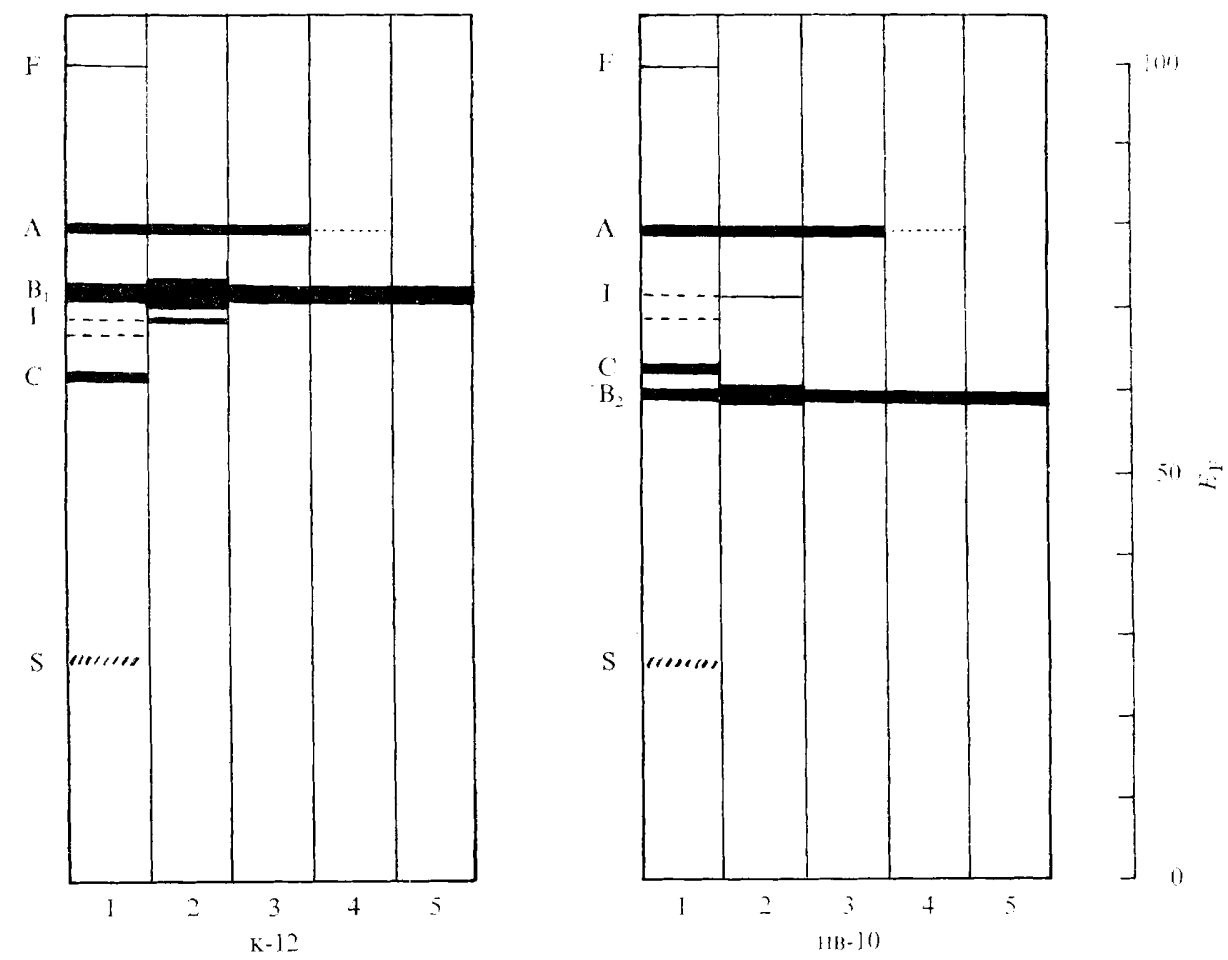

Fig. I. Diagrammatic representation of mobility and specificity of esterase bands (strains: $\mathrm{K}-\mathrm{I} 2$ and HB-10). Substrates used: I, $\beta$-naphthyl acetate; $2, \alpha$-naphthyl acetate; 3 , indoxyl acetate; 4 , $\alpha$-naphthyl butyrate; $5, \beta$-naphthyl butyrate. 0 : Origin; the thickness of the line indicates the relative importance of the bands.

Table 3. Characteristics of esterase bands of Escherichia coli

Substrates hydrolysed

\begin{tabular}{|c|c|c|c|c|c|c|c|c|c|c|c|}
\hline \multirow[b]{2}{*}{$\begin{array}{c}\text { Esterase } \\
\text { bands }\end{array}$} & \multicolumn{3}{|c|}{ Acetates } & \multicolumn{2}{|c|}{ Butyrates } & \multicolumn{2}{|c|}{$\begin{array}{c}\text { Heat } \\
\text { denaturation }\end{array}$} & \multicolumn{2}{|c|}{$\begin{array}{c}\text { Inhibition } \\
\text { by DFP }\end{array}$} & \multicolumn{2}{|c|}{$\begin{array}{c}\text { Effect } \\
\text { of PHMB }\end{array}$} \\
\hline & $\begin{array}{c}\beta- \\
\text { Naphthyl }\end{array}$ & $\begin{array}{c}\alpha- \\
\text { Naphthyl }\end{array}$ & Indoxyl & $\begin{array}{c}\alpha- \\
\text { Naphthyl }\end{array}$ & $\begin{array}{c}\beta- \\
\text { Naphthyl }\end{array}$ & $\overbrace{60^{\circ} \mathrm{C}}$ & $70^{\circ} \mathrm{C}$ & & & & $\mathrm{M} \mathrm{IO}^{-2} \mathrm{M}$ \\
\hline$F$ & + & - & - & - & - & - & - & - & - & + & - \\
\hline A & + & + & + & $( \pm)$ & - & - & - & - & - & + & - \\
\hline B & + & + & + & + & + & + & - & - & - & a & $\mathrm{a}$ \\
\hline C & + & - & - & - & - & - & - & + & + & + & + \\
\hline $\mathrm{S}$ & + & - & - & - & $( \pm)$ & + & $( \pm)$ & + & - & + & + \\
\hline
\end{tabular}

+ , esterase activity; $( \pm)$, very weak activity; - , no activity; a, alteration of mobility

already described. In experiments examining the influence of acrylamide concentration upon the electrophoretic separations, bands $\mathrm{A}$ and $\mathrm{B}_{1}$ of Escherichia coli $\mathrm{K}-12$ were distinctly separated from each other only at $5 \%(\mathrm{w} / \mathrm{v})$ acrylamide and more, whereas bands $\mathrm{C}$ and $\mathrm{S}$ were distinct at $3 \%(\mathrm{w} / \mathrm{v})$ acrylamide and in agarose gel; bands $\mathrm{A}$ and $\mathrm{B}_{2}$ of $E$. coli $\mathrm{HB}-\mathrm{IO}$ separated at $3 \%$ acrylamide and in agarose gel, the relative positions of bands $\mathrm{B}_{2}$ and $\mathrm{C}$ varied with the acrylamide concentration.

Trypsin hydrolysis, heat inactivation, DFP inhibition and PHMB effect. Trypsin destroyed all the esterase bands. The other result are summarized in Table 3 . The bands $B$ were stable 


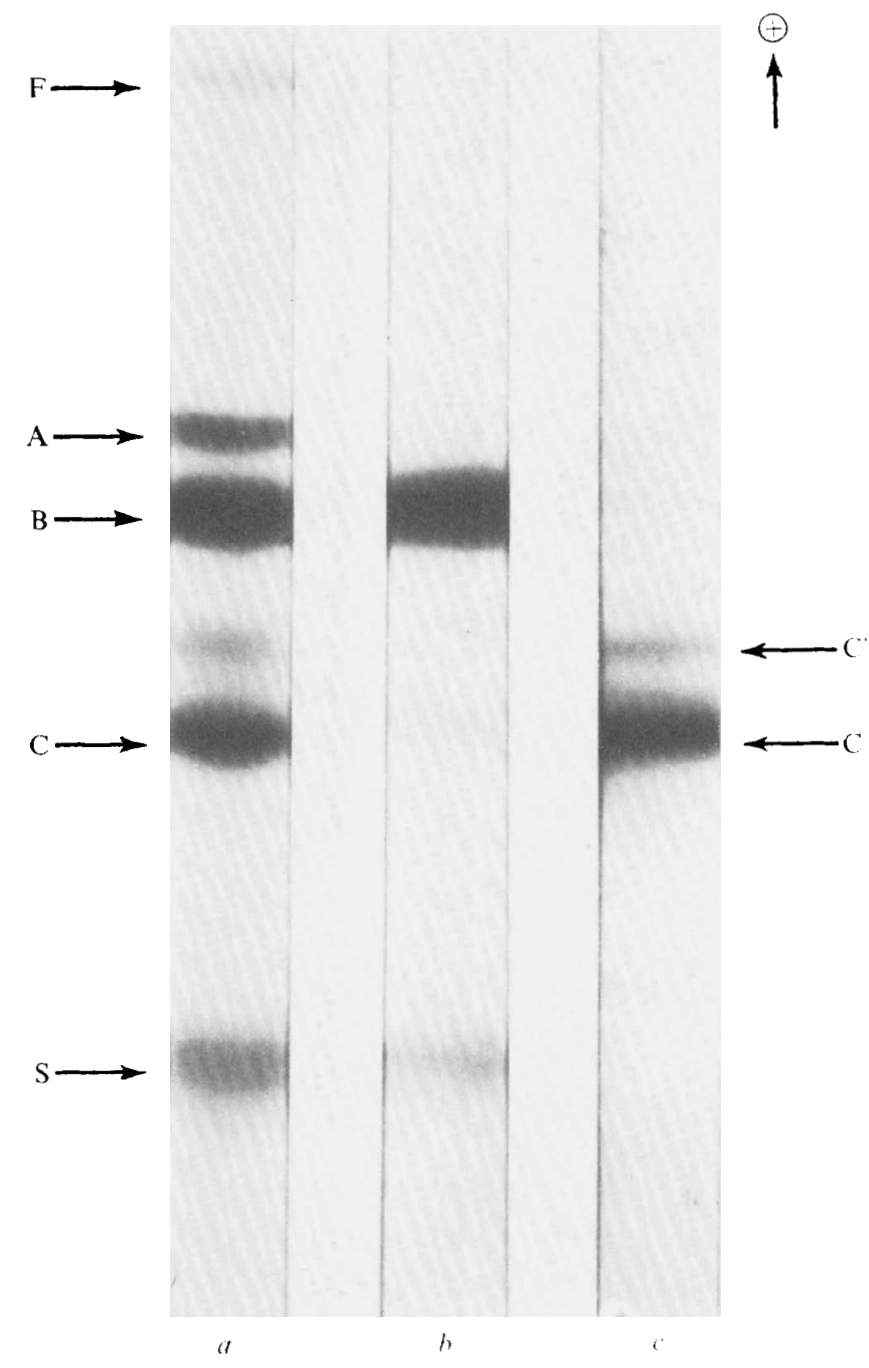

Fig. 2. Heat inactivation and DFP inhibition (strain HB-14). Horizontal slab acrylamide-agarose gel electrophoresis was performed using $7 \%(\mathrm{w} / \mathrm{v})$ acrylamide and discontinuous tris-glycine buffer, pH 8.7. Enzyme activity visualized with naphthanil diazo blue B (Dajac laboratories, Philadelphia, Pennsylvania, U.S.A.) as dye coupler and $\beta$-naphthyl acetate as substrate (Uriel, 196I). $a$, Untreated preparation; $b$, heated at $60 \mathrm{C}$ for Io min; $c$, with DFP $2 \times 10^{-3} \mathrm{M}$.

at $60^{\circ} \mathrm{C}$ for 10 min while esterase bands $\mathrm{F}, \mathrm{A}$ and $\mathrm{C}$ under the same conditions were inactivated (Fig. $2 b$ ). In certain cases, band A was only partly inactivated but inactivation was complete in $30 \mathrm{~min}$ at this temperature. All esterases were inactivated at $70^{\circ} \mathrm{C}$ in $10 \mathrm{~min}$; however, the bands $\mathrm{S}$ showed some residual activity. DFP inhibited the esterase bands $\mathrm{F}, \mathrm{A}$, $\mathrm{B}$ and $\mathrm{S}$ but the bands $\mathrm{C}$ remained active (Fig $2 c$ ). A minor band $\left(\mathrm{C}^{\prime}\right)$ resistant to DFP and migrating faster than band $\mathrm{C}$ was very often associated. The addition of PHMB in increasing concentration $\left(\mathrm{IO}^{-4}\right.$ to $\left.10^{-2} \mathrm{M}\right)$ to the crude extracts increased the mobility of the $\mathrm{B}$ bands. At $10^{-2} \mathrm{M}-\mathrm{PHMB}$, the $\mathrm{F}$ and $\mathrm{A}$ bands disappeared, whereas the $\mathrm{C}$ and $\mathrm{S}$ bands remained unchanged. 

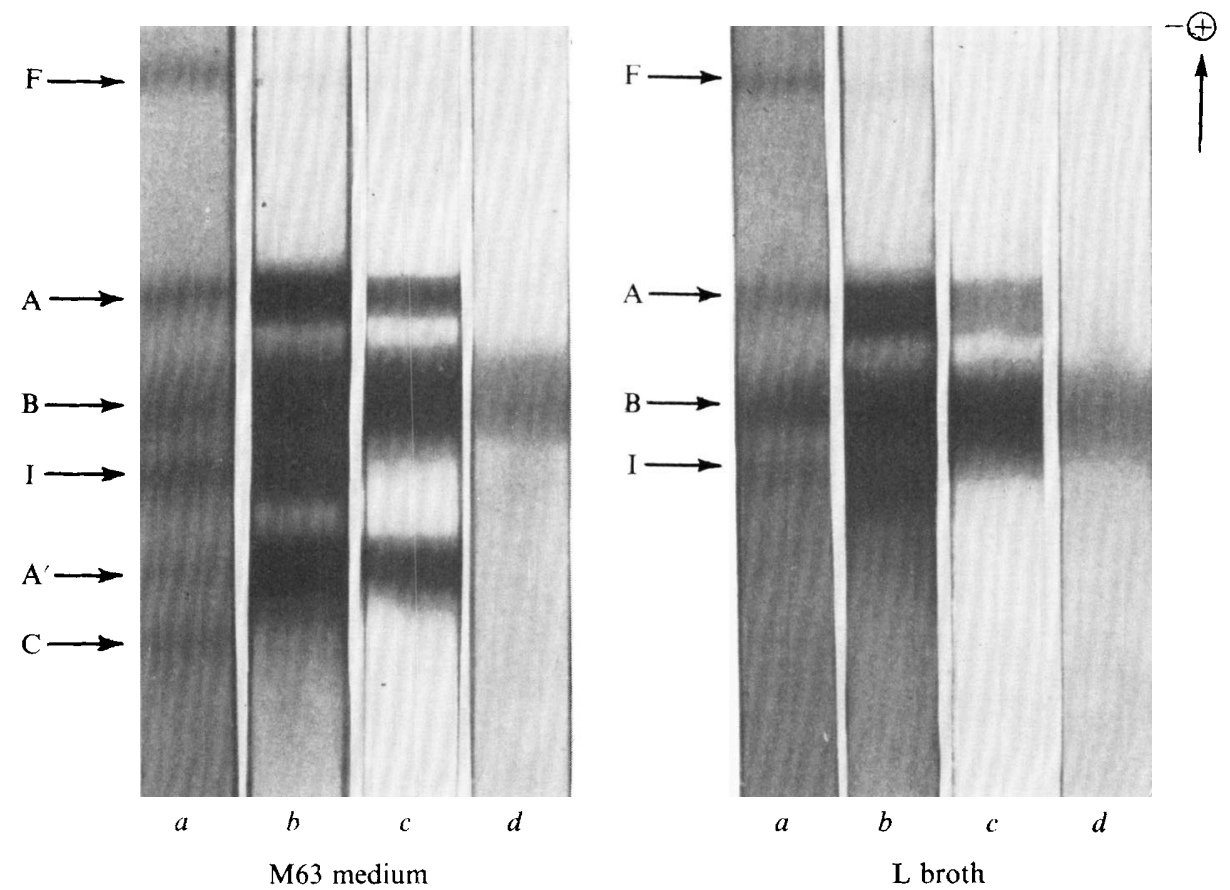

Fig. 3. Effect of composition of the growth medium on esterase pattern. Zymogram of strain LM-26 harvested in logarithmic phase. On M63 medium, the following esterase bands were observed: F, A, $\mathbf{B}, \mathbf{I}, \mathbf{A}^{\prime}, \mathbf{C}$ and $\mathrm{S}$ (the band $\mathrm{S}$ is not represented in the Figure). Band $\mathrm{A}^{\prime}$ (specificity 3 ) was stable at $60^{\circ} \mathrm{C}$ for Io min. On $\mathrm{L}$ broth, the $\mathrm{A}^{\prime}$ and $\mathrm{C}$ bands were not detected. Staining was carried out as described by Uriel (196I) using: $a$, $\beta$-naphthyl acetate; $b, \alpha$-naphthyl acetate; $c$, indoxyl acetate; $d, \beta$-naphthyl butyrate.

\section{Influence of growth conditions}

Various strains of Escherichia coli were studied (see Table 1). The bacteria in stationary phase on M63 medium showed esterase bands very similar to those of bacteria in logarithmic phase on the same medium, whereas in logarithmic phase on L broth the esterase band C was either strongly diminished or undetected.

The effect of composition of the growth medium on the formation of esterase is best illustrated with LM-26 strain (Fig. 3). This evidence may indicate the existence of regulatory systems controlling the synthesis of certain esterases.

\section{Electrophoretic distribution}

Using $\beta$-naphthyl acetate as substrate, five to eight esterase bands, strongly or weakly stained, were usually found for the 25 strains growing exponentially on M63 medium. The differences in electrophoretic patterns were sufficient for identifying most strains examined.

The results obtained for esterase bands A, B, C, F and S are represented diagrammatically in Fig. 4. The bands $F$ and $S$ were detected in all the strains except band $S$ in the case of strain LM-I 27. Electrophoretic uniformity of these bands was observed with the exception of strain HB-5 (F band) and strain LM-86 ( $\mathrm{S}$ band). The bands $\mathrm{A}$ and $\mathrm{B}$ were observed in almost all strains, although the band A in strains HB- 17 and HB- $\mathrm{I} 2$ and band B in strain LM-I 26 were not detected. All strains have an esterase band $\mathrm{C}$ resistant to DFP. The B and C bands of strains 


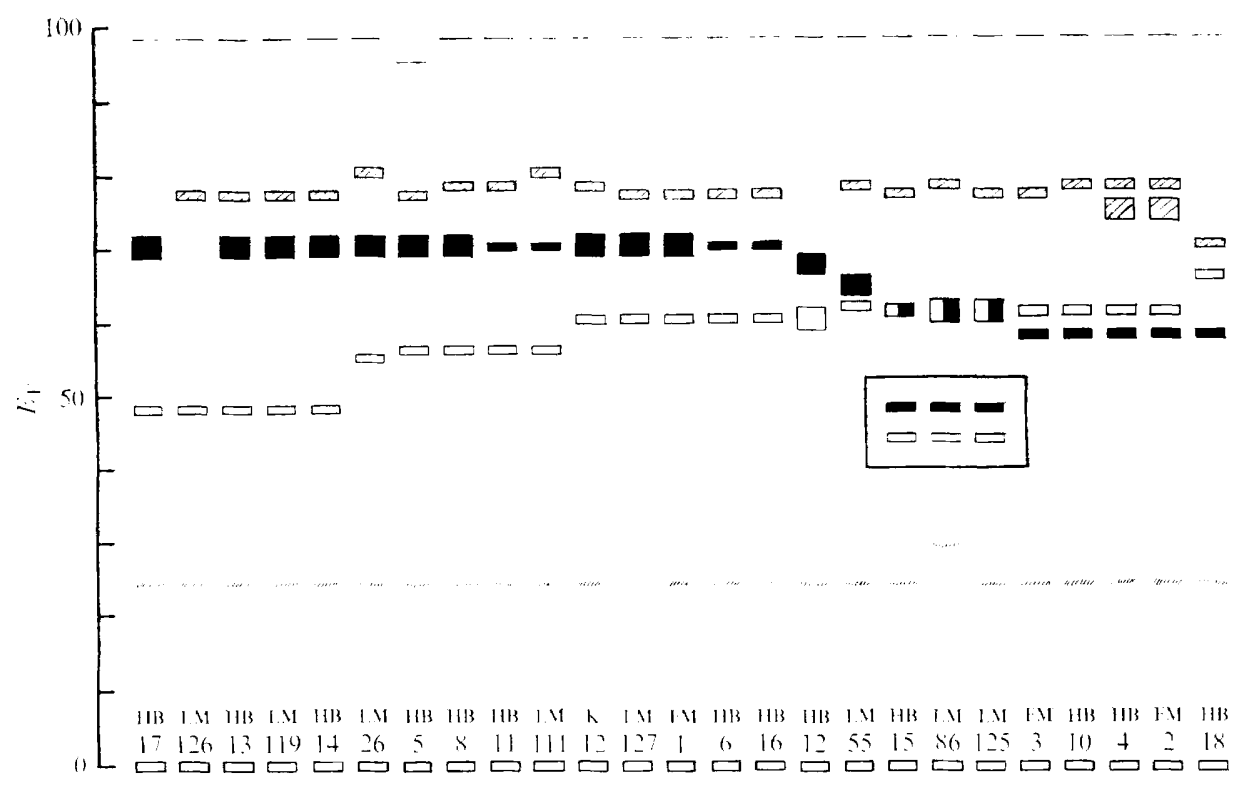

Fig. 4. Diagrammatic representation of esterase patterns of the 25 Escherichia coli strains: band $\mathrm{A} ; \square$, band $\mathrm{B} ; \mathrm{\square}$, band $\mathrm{C}$; - , band $\mathrm{F}$; yllt/l, band $\mathrm{S}$. Horizontal acrylamide agarose gel electrophoresis was performed using $7^{\prime \prime}(\mathrm{w} / \mathrm{v})$ acrylamide and discontinuous tris-glycine buffer, $\mathrm{pH} 8.7$. Insert shows pattern of esterases $\mathrm{B}$ and $\mathrm{C}$ after electrophoresis in a $0.01 \mathrm{M}-\mathrm{phosphate}$ buffer, $\mathrm{pH} 7$.

HB-I 5, LM-86 and LM-I 25 which migrated as a single band in the tris-glycine buffer, $\mathrm{pH}, 8 \cdot 7$ were separated by electrophoresis in the phosphate buffer, $\mathrm{pH} 7$. Esterase bands A, B and C each showed several types of electrophoretic mobilities. In the diagram (Fig. 4) the bands B are recorded in decreasing order of mobility and the bands $C$ are ranged in increasing order. The $B_{2}$ bands were found with the fastest $C$ bands. The fact that the differences in $C$ band mobilities also occur in agarose gel leads one to infer that this variability is linked to differences in the electrical charge of the molecules.

Several strains were distinguished by an unusual pattern of esterases: strain HB-1 3 showed an anomalous large band $\left(E_{\mathrm{F}} \simeq 40\right.$ ) that was inactivated at $37^{\circ} \mathrm{C}$ for $60 \mathrm{~min}$, strain LM-26 showed a strong band I and a band $\mathrm{A}^{\prime}$ resistant to $60^{\circ} \mathrm{C}$, strain $\mathrm{HB}-8$ showed a band (specificity 1) migrating towards the cathode, band B of the strain LM-55 was inactivated at $60{ }^{\circ} \mathrm{C}$, strains FM-2 and HB-4 showed a doubling of band A.

\section{DISCUSSION}

The results obtained with 25 strains of Escherichia coli showed that five kinds of esterase bands can be clearly distinguished (Table 3). The differences in their characteristics, the independence of their electrophoretic variations among the strains and the fact that each individual band may be absent independently suggest that these esterases are coded by different structural genes.

$\mathrm{A}$ and $\mathrm{B}$ esterase bands have several common characteristics. They hydrolyse $\alpha$ - and $\beta$ naphthyl and indoxyl acetates and they are inhibited by DFP. It is likely that their active sites are related. In contrast, $C$ band appears to be very different as evidenced by its narrow esterolytic activity it resistance to DFP and its electrophoretic behaviour in the presence of 
PHMB. Complementary research is needed to determine the genetics and the structural and functional properties of these three kinds of esterases. It would also be particularly interesting to establish the relationships between $\mathrm{A}$ and $\mathrm{B}$ bands.

A striking finding is the constancy with which the esterases of all strains examined preserve their specificity class and their susceptibility or resistance to heat and to DFP. This would indicate that these characteristics might have significance in the physiology of Escherichia coli and, if so, that they might be useful as a molecular element of taxonomy.

On the other hand, variations in the electrophoretic mobility of bands $\mathrm{A}, \mathrm{B}$ and $\mathrm{C}$ were very often observed. This heterology is in agreement with the observations of Bowman, Brubaker, Frischer \& Carson ( 1967 ) concerning glucose-6-phosphate dehydrogenase and phosphogluconate dehydrogenase of Escherichia coli.

The interpretation of the similarities and differences in the electrophoretic mobility of enzymes has been discussed (Shaw, 1965; Bowman et al. 1967; Markert \& Whitt, I968; Baptist, Shaw \& Mandel, I969; Gasser, 1970). One may therefore suppose that identical electrophoretic migrations of the homologous esterase bands reflect homologies in amino acid sequences and that the electrophoretic variants reveal an intraspecific differentiation of the molecular structures of the esterase that has arisen during evolution of the microbial world.

The author thanks Mademoiselle Odile Jeannequin for technical assistance.

\section{REFERENCES}

Baptist, J. N., Shaw, C. R. \& MANDEL, M. (1969). Zone electrophoresis of enzymes in bacterial taxonomy. Journal of Bacteriology 99, $180-188$.

Bowman, J. E., Brubaker, R. R., Frischer, H. \& Carson, P. E. (I967). Characterization of Enterobacteria by starch-gel electrophoresis of glucose-6-phosphate dehydrogenase and phosphogluconate dehydrogenase. Journal of Bacteriology 94, 544-55I.

CANN, J. R. \& GOAD, W. B. (I968). Two or more electrophoretic zones from a single macromolecule. Annals of the New York Academy of Sciences 15I, 638-649.

CANN, D. C. \& Willox, M. E. (1965). Analysis of multimolecular enzymes as an aid to the identification of certain rapidly growing mycobacteria, using starch gel electrophoresis. Journal of Applied Bacteriology 28, $165-173$.

Colwell, R. R., Adeyemo, V. I. \& KiRtland, H. H. (1968). Esterases and DNA base composition analysis of Vibrio cholerae and related vibrios. Journal of Applied Bacteriology 31, 323-335.

El-ShaRkAwY, T. A. \& HUISINGH, D. (197I $a$ ). Electrophoretic analysis of esterases and other soluble proteins from representatives of phytopathogenic bacterial genera. Journal of General Microbiology 68, 149-I54.

El-Sharkawy, T. A. \& Huisingh, D. (1971 b). Differentiation among Xanthomonas species by polyacrylamide gel electrophoresis of soluble proteins. Journal of General Microbiology 68, 155-165.

GASSER, F. (1970). Electrophoretic characterization of lactic dehydrogenase in the genus Lactobacillus. Journal of General Microbiology 62, 223-239.

GoulLET, Ph. (1970). Diverses formes d'activités estérasiques chez Escherichia coli. Comptes rendus hebdomadaires des séances de l'Académie des Sciences (série D) 271, 2208-221 I.

GoulLet, Ph. (197I). Caractérisation et répartition moléculaire des activités estérasiques de diverses Enterobacteriaceae. Comptes rendıs hebdomadaires des séances de l'Académie des Sciences (série D) 273, 18841887 .

Green, S. S. \& Goldberg, H. S. (1967). Electrophoretic determination of leptospiral enzymes. Journal of Bacteriology 93, 1739-1740.

Hogan, M. A. \& COLWELl, R. R. (1969). DNA base composition and esterase patterns of bacteria isolated from deep sea sediments. Journal of Applied Bacteriology 32, 103-I I I.

HUNTER, R. L. \& MARKERT, C. L. (I957). Histochemical demonstration of enzymes separated by zone electrophoresis in starch gels. Science, New York 125, 1294-1295. 
Lawrence, S. H., Melnick, P. J. \& Weimer, H. E. (1960). A comparison of serum proteins and enzymes by starch-gel electrophoresis. Proceedings of the Society for Experimental Biology and Medicine ro5, $572-575$.

LENNox, E. S. (1955). Transduction of linked genetic characters of the host by bacteriophage Pı. Virology I, 190-206.

Lowry, O. H., Rosebrough, N. J., Farr, A. L. \& Randall, R. J. (1951). Protein measurement with the Folin phenol reagent. Journal of Biological Chemistry 193, 265-275.

LUNı, B. M. (1965). A comparison by the use of gel electrophoresis of soluble protein components and esterase enzymes of some group D streptococci. Journal of General Microbiology 40, 4I 3-4I9.

Markert, C. L. \& Whitt, G. S. (I968). Molecular varieties of isozymes. Experientia 24, 977-Io88.

Morichi, T., Sharpe, M. E. \& Reiter, B. (1968). Esterases and other soluble proteins of some lactic acid bacteria. Journal of General Microbiology 53, 405-4I4.

Murphy, P. M. \& MASTERSON, C. L. ( I970). Determination of multiple forms of esterases in Rhizobium by paper electrophoresis. Journal of General Microbiology 6I, 12 I-I 29.

NakAYama, Y. \& TAKeYA, K. (1967). Esterase zymogram method for classifying mycobacteria. Nature, London $\mathbf{2 1 3}, 504$.

NorRIS, J. R. (1962). Electrophoretic analysis of bacterial esterase systems - an aid to taxonomy. Journal of General Microbiology $\mathbf{2 8}$, vii.

Norris, J. R. (1964). The classification of Bacillus thuringiensis. Journal of Applied Bacteriology 27, 439-447.

Pardee, A. B., JACOB, F. \& Monod, J. (1959). The genetic control and cytoplasmic expression of "inducibility' in the synthesis of $\beta$-galactosidase by E. coli. Journal of Molecular Biology 1, 165-178.

Robinson, K. (1966). An examination of Corynebacterium spp. by gel electrophoresis. Journal of Applied Bacteriology 29, 179-184.

Shaw, C. R. (1965). Electrophoretic variation in enzymes. Science, New York 149, 936-943.

Stewart, D. B. \& Stewart, D. J. (197I). Esterases and phosphatases of Escherichia coli serotypes isolated from the pig. Journal of General Microbiology 65, I $75-184$.

UrIEL, J. (1961). Caractérisation des cholinestérases et d’autres estérases carboxyliques après électrophorèse et immunoélectrophorèse en gélose (application à l'étude des estérases du sérum humain normal). Annales de l'Institut Pasteur ror, I04-1 19.

Uriel, J. (1966). Méthode d’électrophorèse dans des gels d'acrylamide-agarose. Bulletin de la Société de Chimie Biologique 48, 969-982. 